\title{
Vertical distribution of macrozoobenthos within the sediment on the continental slope of the Goban Spur area (NE Atlantic)
}

\author{
Els Flach*, Carlo Heip \\ Centre for Estuarine and Coastal Ecology, Netherlands Institute of Ecology (NIOO-CEMO), Vierstraat 28, \\ 4401 EA Yerseke, The Netherlands
}

\begin{abstract}
Macrofauna density and biomass were estimated in 4 sediment layers $(0-1,1-5,5-10$ and $10-15 \mathrm{~cm}$ ) from 12 stations ranging from 185 to $4460 \mathrm{~m}$ water depth in the Goban Spur area (NE Atlantic). At the same stations profiles of median grain size, \% organic carbon and \% total nitrogen were measured to a sediment depth of $15 \mathrm{~cm}$. Macrofauna densities decreased exponentially from $-8000 \mathrm{~m}^{-2}$ at $208 \mathrm{~m}$ to $-550 \mathrm{~m}^{-2}$ at the deepest stations ( 3673 and $4460 \mathrm{~m}$ ). Most of the macrofauna was concentrated in the upper $1 \mathrm{~cm}$ of the sediment. The highest proportion (70 to $80 \%$ ) was in the upper $1 \mathrm{~cm}$ found at intermediate depths (670 to $1425 \mathrm{~m}$ ), whereas at the deeper stations the fauna was more evenly distributed. Polychaeta were the most abundant taxon, with a high proportion of subsurface deposit-feeders at the deep stations and a high proportion of filter-feeders plus surface deposit-feeders at intermediate depth. Biomass values showed a very variable pattern, mainly due to a few extremely large individuals at some of the stations. Excluding these large individuals, a maximum biomass value was observed around $1000 \mathrm{~m}$ water depth. At most stations the biomass was concentrated below the upper $1 \mathrm{~cm}$, which was also reflected in the vertical distribution pattern of the mean individual weight, showing small individuals in the upper $1 \mathrm{~cm}$ and larger individuals $\mathrm{in}$ the deeper sediment layers. Both density and biomass fell within the range of values usually observed at these depths. Only the biomass value at $1034 \mathrm{~m}$ was extremely high and concentrated in the upper $1 \mathrm{~cm}$ of the sediment. This may be due to pulsed inputs of fresh material at this station, whereas at the deepest stations $(3673$ and $4460 \mathrm{~m})$ a constant low input of refractory material supports the fauna of mainly deep-living subsurface depositfeeders. Median grain size decreased with increasing water depth from $-90 \mu \mathrm{m}$ at $208 \mathrm{~m}$ to $-8 \mu \mathrm{m}$ below $2000 \mathrm{~m}$. The vertical profiles showed very homogeneous sediments to a depth of $15 \mathrm{~cm}$ at all stations, probably due to bioturbation by the relatively abundant deposit-feeders. In general, the $\%$ of total $\mathrm{N}$ and organic $\mathrm{C}$ in the upper $1 \mathrm{~cm}$ of the sediment increased with increasing water depth, but showed a peak at $-1000 \mathrm{~m}$. The $\% \mathrm{C}$ and especially $\mathrm{N}$ were lower in the deeper sediment layers at the deeper stations, resulting in C: $N$ ratios of $\sim 12$ to 15 in contrast to $\sim 7$ to 8 in the upper $1 \mathrm{~cm}$ of the sediment. The $\mathrm{C}: \mathrm{N}$ ratio at the midslope stations $(\sim 1000$ to $1500 \mathrm{~m})$ did not decrease with depth in the sediment, indicating a rapıd burial of organic matter by the hıgh numbers of surface deposit-feeders at these stations.

KEY WORDS: Vertical distribution Macrozoobenthos - Continental slope Grain size - C:N ratıo
\end{abstract}

\section{INTRODUCTION}

This study is part of the Ocean Margin EXchange (OMEX) programme of the EU. The general aim of OMEX is to study the physical, chemical and biological processes at ocean margins - the shelf break and the continental slope - that determine the transport of

•E-mail: flach@cemo.nioo.knaw.nl material from the shelf to the deep sea. The aim of the subproject Benthic Biology within OMEX is to evaluate the role of biological processes in the cycling of particulate organic material in the benthic boundary layer and in sediments. As part of this subproject the vertical distribution of the macrozoobenthic community within the sediment was examined.

Benthic infauna play an important direct and indirect role in determining the fate of organic material 
arriving at the sediment-water interface. The fauna physically transports particles through the benthic boundary layer. Organic material is stored temporarily as biomass, and by feeding and excretion the burial and regeneration rates of carbon in the sediment are altered (Grehan et al. 1994). Bioturbation due to moving animals substantially modifies the physical, chemical and biological properties of sediments (Boudreau 1994, Soetaert et al. 1996). The majority (usually $80 \%$ or more by numbers of macrofaunal taxa) of animals captured in deep-sea cores are deposit-feeders (Jumars \& Gallagher 1982). Bulk feeding by deposit-feeders in an environment of low sedimentation rates results in intense reworking of the sediment and has considerable importance when trying to understand geochemical cycles and interpret the geological record represented by the sediment (Gage \& Tyler 1991).

Structural characteristics of benthic communities can give important indirect but time integrated information about the quantity and quality of organic material arriving at the sea floor and about the burial of organic material in the sediments. The relationship between expected vertical distributions of macrofauna and organic food supply has been discussed by Jumars et al. (1990). If the majority of usable food for depositfeeders arrives as pulses of labile matter, a selectively advantageous feeding strategy is to sequester as much as possible of this material as soon as it is available.
Most heterotrophs are concentrated near the sediment surface and one possible strategy of sequestering may therefore be to bury the catch deep below the sediment-water interface.

Until now relatively few efforts have been made to quantify the vertical distribution of macrofauna in the sediment along depth gradients and these studies are restricted to small depth ranges [e.g. from 115 to $472 \mathrm{~m}$ water depth, Shirayama \& Horikoshi (1982); from 30 to $620 \mathrm{~m}$, Josefson (1989); and from 240 to $815 \mathrm{~m}$, Grehan et al. (1994)]. In our study we compared the vertical distribution of macrofauna to a depth of $15 \mathrm{~cm}$ along a transect from 208 to $4460 \mathrm{~m}$ water depth. At the same stations vertical profiles of median grain sizes and percentages of organic carbon and total nitrogen were also measured to a depth of $15 \mathrm{~cm}$.

\section{MATERIAL AND METHODS}

Sampling sites. Samples were taken along the OMEX transect with the RV 'Charles Darwin' from May 15 to June 11,1994 . The OMEX transect is situated at the Goban Spur area in the NE Atlantic (Fig. 1) and runs from the continental shelf of the Celtic Sea, along the continental slope, down to the Porcupine Abyssal Plain at water depths ranging from 208 to $4460 \mathrm{~m}$. Besides the designated OMEX stations ( $A, I, B$, II, F, III, E) 5 extra stations (8 to 12) were sampled dur-

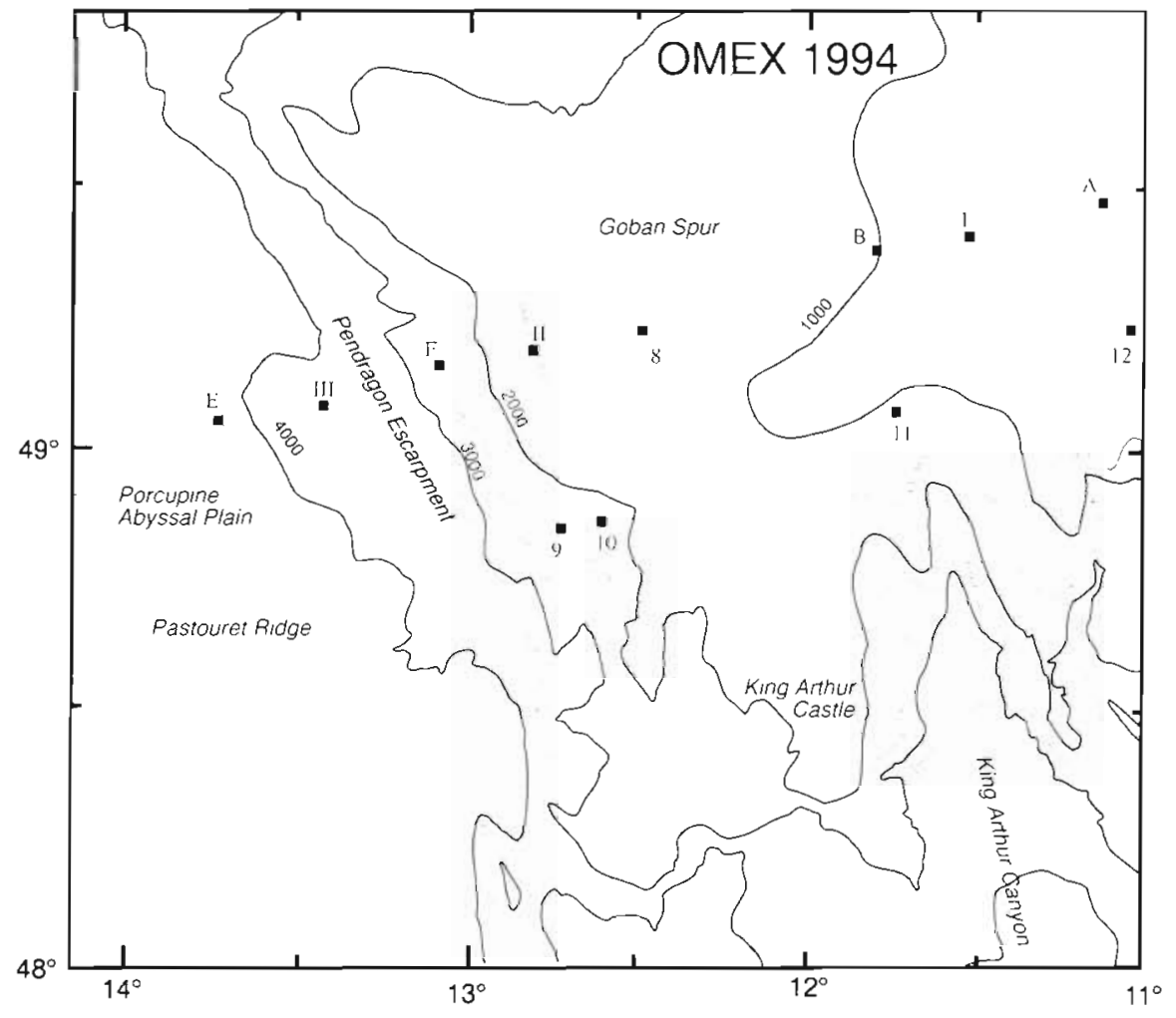

Fig. 1. Location of the sampling stations of the original OMEX transect (A, I, B, II, F, III, E) and the extra sta. tions ( 8 to 12). Copied and modified with permission from van Weering \& de Stigter (1995) 
ing the Charles Darwin cruise (Fig. 1). The characteristics of the sampling stations are given in Table 1 . Bottom water temperature decreases from $\sim 11^{\circ} \mathrm{C}$ at the shallowest stations $(-200 \mathrm{~m})$ to $\sim 2.5^{\circ} \mathrm{C}$ at the deepest stations $(\sim 4 \mathrm{~km})$. Salinity also decreases with increasing water depths from -35.5 psu at the shallowest stations to -34.9 psu at the deepest stations.

Macrofauna. Macrofauna samples were taken with the circular boxcorer of the Netherlands Institute of Sea Research (NIOZ). Because of logistic reasons different numbers of boxes of different sizes were taken at different stations. Boxcores with diameters of $30 \mathrm{~cm}$ (mainly used at the shallow stations) and $50 \mathrm{~cm}$ were used (Table 1). Some subsamples were taken out of some of the boxes for other purposes, resulting in different sample sizes at the different stations (Table 1). For this reason only mean densities and biomass $\mathrm{m}^{-2}$ are given (see Fig. 10 for sample variability in density and biomass).

Boxcore samples were sliced in sediment layers of $0-1,1-5,5-10$ and $10-15 \mathrm{~cm}$ and sieved on a $0.5 \mathrm{~mm}$ sieve. Samples were stored in $4 \%$ formaldehyde, stained and sorted under a stereo microscope. Biomass was estimated in wet weight per major taxon after drying the individuals for a few seconds on absorbent paper. Because of the small size of most individuals no attempt was made to puncture the shells of bivalves to drain them of water. Weight was measured to within $0.1 \mathrm{mg}$ accuracy. Biomass values were converted into organic $\mathrm{C}$ content per major taxon using the conversion factors given by Rowe (1983). Meiofaunal taxa (e.g. Nematoda, Harpacticoida) were excluded from all analyses. Feeding types of the Polychaeta were based on taxonomic affiliation of families (determined by $\mathrm{M}$. Lavaleye) after Fauchald \& Jumars (1979).

The data were analysed with ANOVA on $\log (x+1)$ transformed density and biomass data per replicate box and per sediment layer.
Abiotic factors. Small subcores of $10 \mathrm{~cm}$ diameter were taken out of the boxcores for sediment analysis. Samples were sliced in layers of $5 \mathrm{~mm}$ (from 0 to 20), $10 \mathrm{~mm}$ (from 20 to 100 ) and $50 \mathrm{~mm}$ (from 100 to 150 ) for grain size analysis. Particle size of the sediments was estimated with and without $\mathrm{CaCO}_{3}$ using a Malvern Particle Sizer $3600 \mathrm{EC}$. $\mathrm{CaCO}_{3}$ was determined by gas volumetry (Scheibler method). For C:N ratio analysis, small subcores were sliced in similar layers as for grain size, except for the layer 10 to $15 \mathrm{~cm}$, which was also sliced into $1 \mathrm{~cm}$ layers. These samples were immediately frozen at $-25^{\circ} \mathrm{C}$ on board. The total $\mathrm{N}$ and the organic $\mathrm{C}$ content of the sediments were analysed with a Carlo Erba type NA-1500 elemental analyzer according to Nieuwenhuize et al. (1994). C was partitioned into inorganic and organic fractions by acidification with $25 \% \mathrm{HCl}$ in situ within silver sample cups. The data were pooled for the following layers: $0-1,1-5,5-10$ and $10-15 \mathrm{~cm}$

\section{RESULTS}

\section{Macrofauna}

Density

Macrofauna densities showed an exponential decrease with increasing water depth from $-8000 \mathrm{~m}^{-2}$ at Stn A $(208 \mathrm{~m})$ to $\sim 550 \mathrm{~m}^{-2}$ at the deepest Stns III $(3673 \mathrm{~m})$ and $E(4460 \mathrm{~m})$ along the OMEX transect (Fig 2a). At the extra stations a similar profile was found (Fig. 2b), except for the relatively low densities at $\operatorname{Stn} 12$ (185 $\mathrm{m}$, only 1 small boxcore) and Stn 8 $(1140 \mathrm{~m}$ ). The 3 stations at a depth of $\sim 2200 \mathrm{~m}$ (Stns F, 9 and 10 ) showed a remarkable similarity in density $\left(1434,1472\right.$ and $1379 \mathrm{~m}^{-2}$ respectively).

Table 1. Sampling of macrofauna at the different stations. $\varnothing$ : diameter of boxcore $O_{0}$ : total area sampled. Position, depth, temperature and salinity data copied, with permission, from van Weering (1994)

\begin{tabular}{|c|c|c|c|c|c|c|c|c|}
\hline Stn & Position N & Position W & Depth $(\mathrm{m})$ & Temperature $\left({ }^{\circ} \mathrm{C}\right)$ & Salinuty (psu) & No. of boxcores & $\varnothing(\mathrm{cm})$ & $\left(\mathrm{cm}^{2}\right)$ \\
\hline A & $49^{\circ} 29.7^{\prime}$ & $11^{\circ} 084^{\prime}$ & 208 & 10.51 & 35.48 & 3 & 30 & 2060.6 \\
\hline 1 & $49^{\circ} 24.9^{\prime}$ & $11^{\circ} 31.4^{\prime}$ & 670 & 9.97 & 35.48 & 2 & 30 & 1413.7 \\
\hline$B$ & $49^{\circ} 22.4^{\prime}$ & $11^{\circ} 45.1^{\prime}$ & 1034 & 8.69 & 35.53 & 2 & 50 & 3927.0 \\
\hline Il & $49^{\circ} 11.3^{\prime}$ & $12^{\circ} 49.7^{\prime}$ & 1425 & 7.00 & 35.38 & 2 & 50 & 3927.0 \\
\hline$F$ & $49^{\circ} 09.5^{\prime}$ & $13^{\circ} 05.3^{\prime}$ & 2182 & 3.20 & 34.96 & 2 & 50 & 3769.9 \\
\hline III & $49^{\circ} 05.2^{\prime}$ & $13^{\circ} 25.9^{\prime}$ & 3673 & 2.50 & 34.91 & $2+1$ & $50+30$ & 4633.8 \\
\hline$E$ & $49^{\circ} 02.3^{\prime}$ & $13^{\circ} 42.2^{\prime}$ & 4460 & 2.53 & 34.90 & $2+1$ & $50+30$ & 4633.8 \\
\hline 8 & $49^{\circ} 14.0^{\prime}$ & $12^{\circ} 30.0^{\prime}$ & 1140 & 8.23 & 35.53 & 3 & 50 & 5890.5 \\
\hline 9 & $48^{\circ} 50.5^{\prime}$ & $12^{\circ} 45.0^{\prime}$ & 2190 & 3.36 & 34.96 & 3 & 50 & 5654.9 \\
\hline 10 & $48^{\circ} 51.9^{\prime}$ & $12^{\circ} 38.8^{\prime}$ & 2290 & 3.27 & 34.97 & 2 & 50 & 3927.0 \\
\hline 11 & $49^{\circ} 04.5^{\prime}$ & $11^{\circ} 44.5^{\prime}$ & 1120 & 7.54 & 35.45 & 3 & 50 & 5890.5 \\
\hline 12 & $49^{\circ} 22.0^{\prime}$ & $11^{\circ} 00.0^{\prime}$ & 185 & 10.58 & 35.49 & 1 & 30 & 706.9 \\
\hline
\end{tabular}




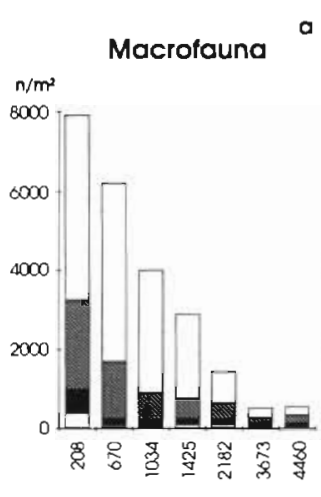

a
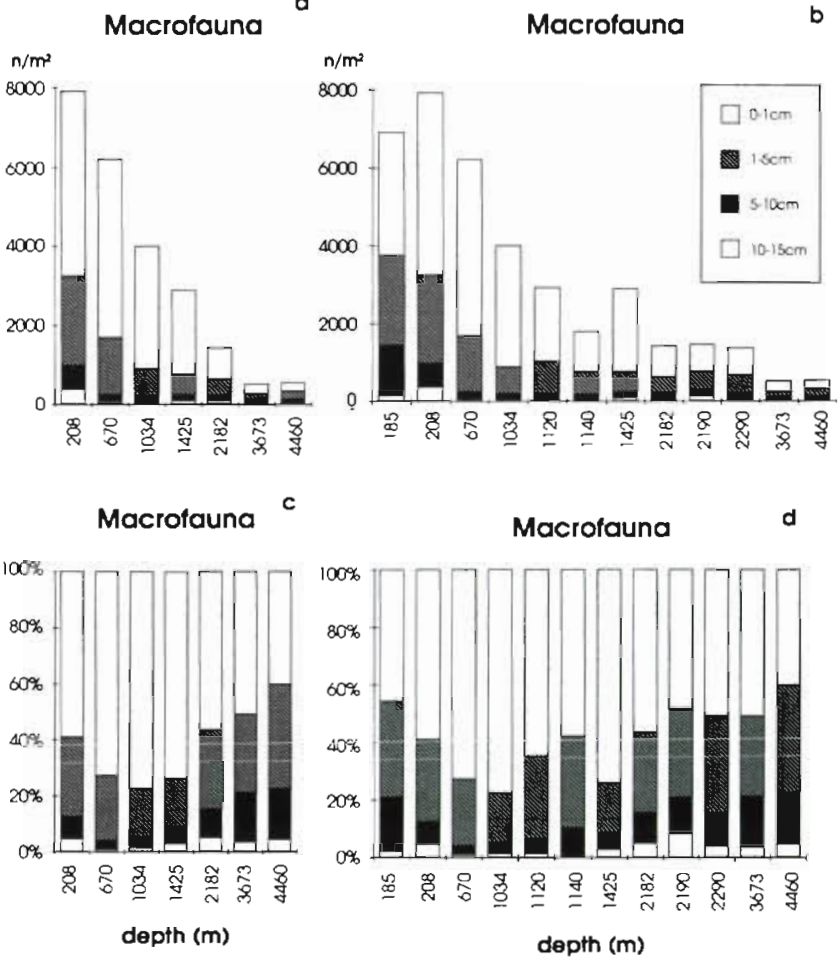

Fig. 2. Macrofauna densities ( $\mathrm{n} \mathrm{m}^{-2}$ ) (a) along the OMEX transect and (b) along the total depth range sampled. Relative (\%) importance of the different sediment layers $(0-1,1-5,5-10$ and 10-15 cm sediment depth) (c) along the OMEX transect and (d) along the total depth range

Based on ANOVA, density of all macrofaunal groups showed significant interaction between station and layer, except for the Mollusca and Echinodermata where separate, highly significant effects of station and layer were found (Table 2). Most of the macrofauna (40 to $80 \%$ ) was found in the upper $1 \mathrm{~cm}$ of the sediment (Fig. 2c, d). Along the OMEX transect an interesting pattern in the vertical distribution was observed, with a relatively lower proportion of animals in the upper sediment layer of both the shallow and deep stations and a relatively higher proportion at intermediate depths (Fig. 2c). At Stn B (1034 m) more than $80 \%$ of the macrofauna was concentrated in the upper $1 \mathrm{~cm}$ of the sediment. A very small fraction of the macrofauna was found below $10 \mathrm{~cm}$ depth, from $-1 \%$ at Stns I and B to $\sim 7 \%$ at Stn E. The extra stations showed a similar pattern (Fig. 2d), although at the 2 stations at $\sim 1100 \mathrm{~m}$ depth relatively low numbers were found in the upper $1 \mathrm{~cm}$ (Fig 2b,d).

Echinodermata were an important taxon on the upper slope to a depth of $\sim 1500 \mathrm{~m}$ (Fig. 3a). Below this depth only very few Echinodermata were found, accounting for only $\sim 1$ to $5 \%$ of the total macrofauna. At mid-slope depths Echinodermata made up $\sim 25 \%$ of the macrofauna (Stns B, 8 and II), except at Stn 11 $(1120 \mathrm{~m})$, where only $\sim 9 \%$ of the macrofauna were Echinodermata. At the shallow Stns 12 , A and I $~ 12 \%$ of the macrofauna were Echinodermata. The vertical distribution of the Echinodermata in the sediment was similar to that of total macrofauna, but with an even more pronounced concentration in the upper $1 \mathrm{~cm}$. At Stns I and B $\sim 90 \%$ of the Echinodermata (mainly juvenile Ophiuroidea) were found in the upper $1 \mathrm{~cm}$, whereas at Stn E only $\sim 28 \%$ lived in the upper $1 \mathrm{~cm}$ (Fig. 3b)

The number of Crustacea was low at both the shallowest (Stns 12 \& A) and the deepest stations (III \& E) (Fig. 3c). The relative share of Crustacea within the total macrofauna, however, increased with increasing water depth from only $\sim 1.4 \%$ at Stn 12 and $\sim 2 \%$ at Stn $A$ to $-33 \%$ at Stn III. The vertical distribution again showed a similar pattern, with the highest proportion of Crustacea found in the upper $1 \mathrm{~cm}$ at intermediate depths (Fig. 3d), although at the stations at $\sim 1100 \mathrm{~m}$ high numbers of relatively large Isopoda were found in the layer between 1 and $5 \mathrm{~cm}$ sediment depth. At the shallowest stations deep burrowing Callianassa $\mathrm{sp}$. were found, accounting for the high percentage below $5 \mathrm{~cm}$ sediment depth.

The highest densities of Mollusca were found at Stn I (Fig 3e), where they made up $\sim 12 \%$ of the macrofauna. This percentage was similar at most of the stations, except at the 2 deepest and 2 shallowest stations, where only $-65 \%$ and $-3 \%$, respectively, of the macrofauna were Mollusca. The vertical distribution was

Table 2. ANOVA results of the OMEX transect. Number $\mathrm{m}^{-2}$ of total macrofauna (Total), Echinodermata (Echi.), Crustacea (Crus.), Mollusca (Mol.), Polychaeta (Pol.) per station, per box and per sediment layer. Biomass and mean individual weight of total macrofauna in $\mathrm{mg}$ org. $\mathrm{C} \mathrm{m}^{-2}$ per station, per box and per sediment layer. Significance: $\cdots p<0.001, \cdots p<0.01, " p<0.05$, $\mathrm{ns}=$ not significant

\begin{tabular}{|c|c|c|c|c|c|c|c|c|}
\hline \multirow[t]{2}{*}{ Source } & \multirow[t]{2}{*}{$d f$} & \multicolumn{5}{|c|}{ Number $\left(\mathrm{m}^{-2}\right)$} & \multirow{2}{*}{$\begin{array}{c}\text { Biomass } \\
\left(\mathrm{mg} \text { org. } \mathrm{C}^{-2}\right)\end{array}$} & \multirow{2}{*}{$\begin{array}{c}\text { Mean individual weight } \\
\left(\mathrm{mg} \text { org } \mathrm{C} \mathrm{m}^{-2}\right)\end{array}$} \\
\hline & & Total & Echi. & Crus. & Mol. & Pol. & & \\
\hline Station & 6 & $\cdots$ & $\cdots$ & $\cdots$ & $\cdot \cdot$ & $\cdots$ & $\cdots$ & $\cdot$ \\
\hline Layer & 3 & $\cdots$ & $\cdots$ & $\cdots$ & $\cdots$ & $\cdots$ & $\cdots$ & $\cdots$ \\
\hline Station $\times$ Layer & 18 & $\cdots$ & ns & $\cdots$ & ns & $\cdots$ & $\cdots$ & $\cdots$ \\
\hline
\end{tabular}



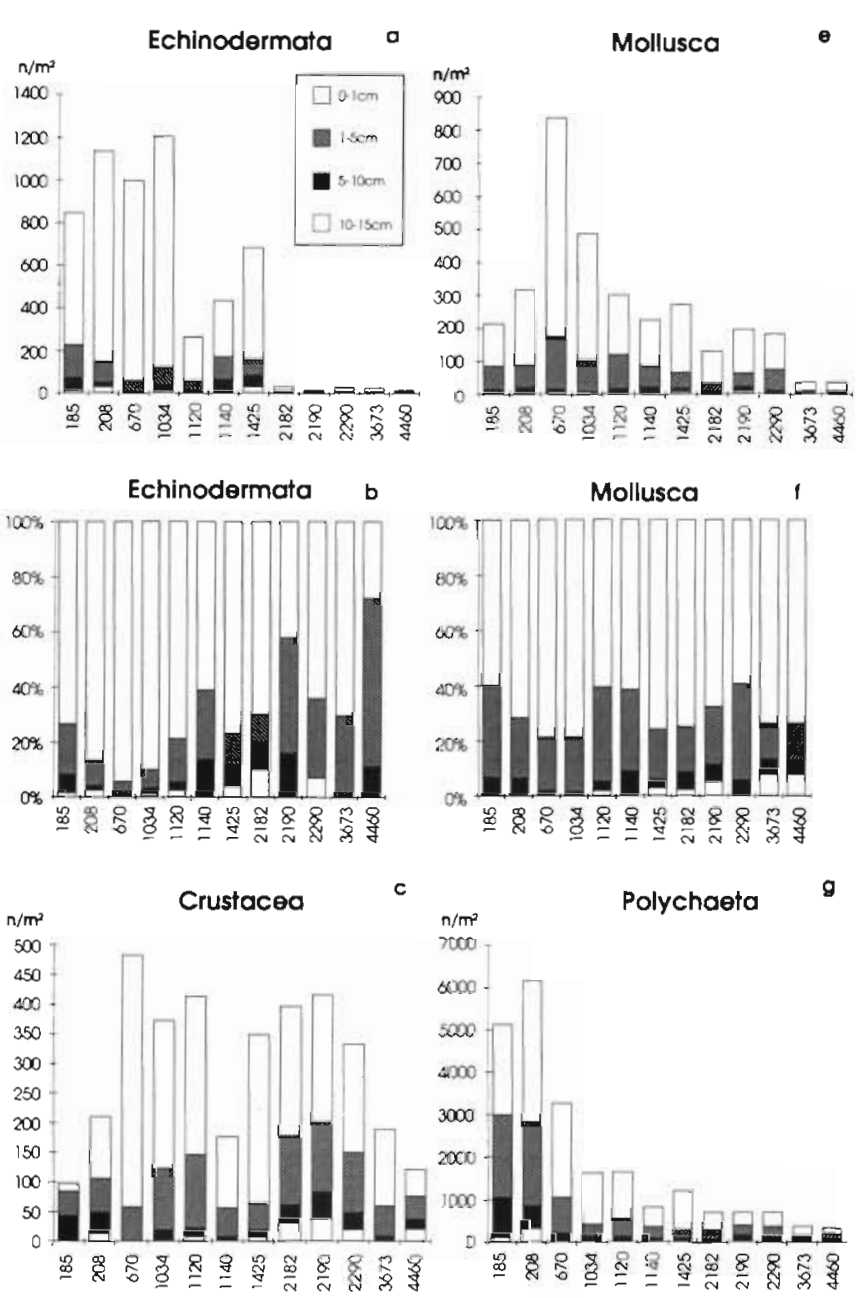

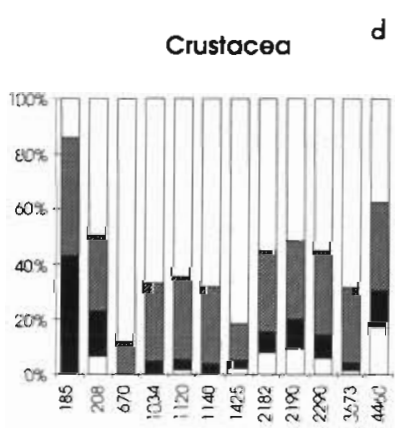

depth (m)

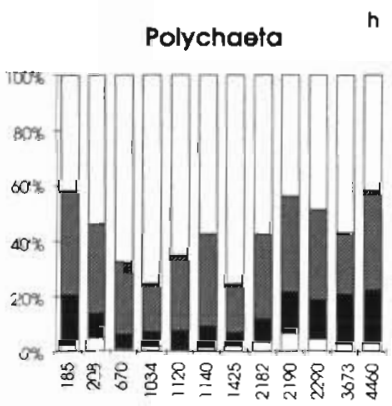

depth (m)
Fig. 3. Densities ( $\mathrm{n} \mathrm{m}^{-2}$ ) and relative (\%) vertical distributions of the 4 major taxa within the sediment along the total water depth range

similar along the whole OMEX transect (Fig. 3f) with $-75 \%$ of the Mollusca living in the upper $1 \mathrm{~cm}$. The proportion of Mollusca found in the deepest sediment layers showed an increase with increasing water depth. The pattern became somewhat different when adding the extra stations, because at most of these sta-

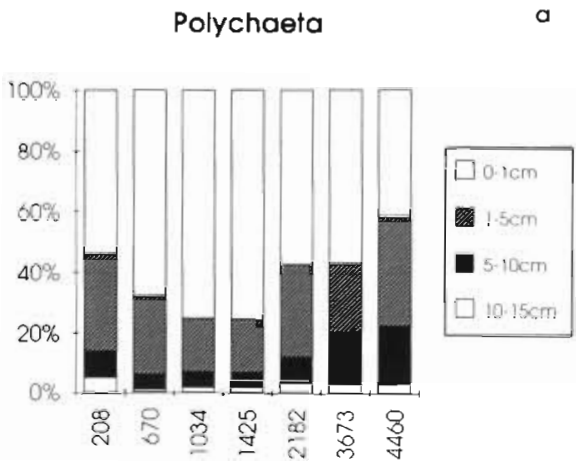

Polychaeta feeding types

b

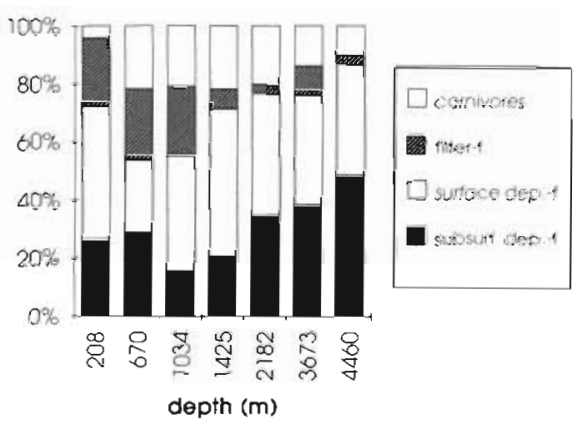

Fig. 4. (a) Relative (\%) vertical distribution of the Polychaeta within the sediment and (b) the relative (\%) frequency of their feeding types along the OMEX transect

tions lower proportions $(-60 \%)$ were found in the upper $1 \mathrm{~cm}$.

Polychaeta were the most abundant taxon at all stations, although their relative share decreased with increasing water depth from $\sim 75 \%$ at the shallowest station $(185 \mathrm{~m})$ to $\sim 40$ to $50 \%$ at mid-slope depths (only $\sim 36 \%$ at $\operatorname{Stn} B$ ) and increased again at the deepest stations to $\sim 60 \%$ The highest density of Polychaeta was found at $\operatorname{Stn} \mathrm{A}\left(\sim 6000 \mathrm{~m}^{-2}\right)$, and density decreased with increasing water depth to $\sim 350 \mathrm{~m}^{-2}$ at the 2 deepest stations (Fig. $3 g$ ). Their vertical distribution in the sediment (Fig. 3h) can be explained by their feeding types. At the deepest stations the high proportion of subsurface deposit-feeding Polychaeta coincided with the highest relative abundance found in the deeper sediment layers (Fig. 4). At Stns B and II a high proportion of filter-feeders and surface deposit-feeders coincided with a high relative density $(-75 \%)$ in the upper $1 \mathrm{~cm}$ of the sediment (Fig. 4).

Biomass

Along the OMEX transect biomass of the macrofauna, expressed in organic C content (Fig. 5a), did not 

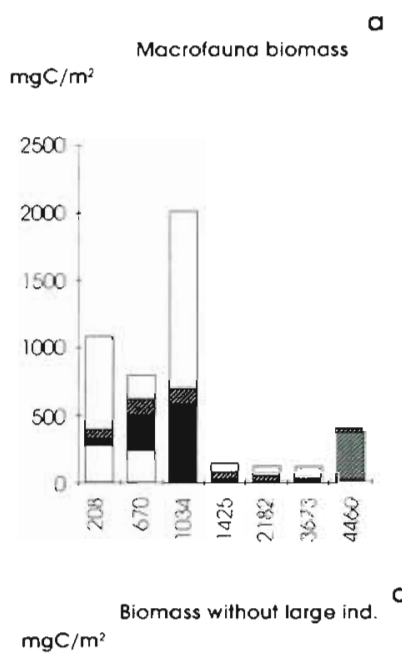

\section{$c$} $\mathrm{mgC} / \mathrm{m}^{2}$
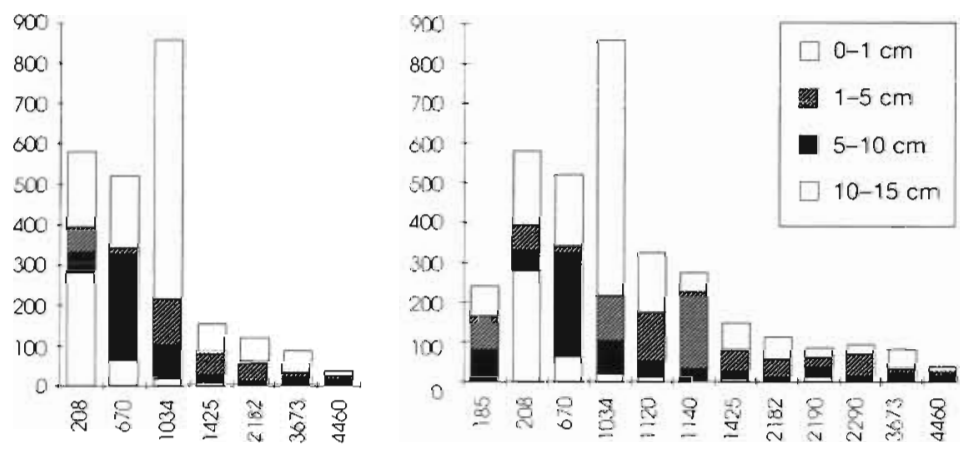

Macrofouna biomass

b

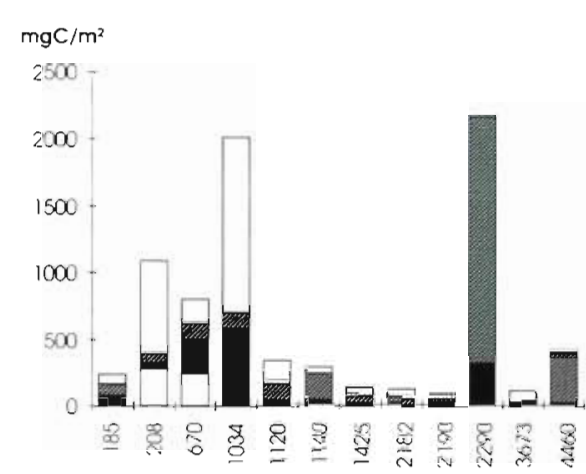

the deepest station (Stn E) was due to a large Holothuroidea (161 $\mathrm{mg} \mathrm{C}$, in the sediment layer between 1 and $5 \mathrm{~cm}$ ); all other animals were small (Fig. 6). With the addition of the extra stations along the depth gradient (Fig. 5b) an even more variable pattern emerged An extremely high biomass value was found at $\operatorname{Stn} 10\left(-2200 \mathrm{mg} \mathrm{C} \mathrm{m}^{-2}\right)$, which was due to 2 large Sipuncula (one of $1060 \mathrm{mg} \mathrm{C}$ in the sediment layer between 1 and $5 \mathrm{~cm}$ and one of $180 \mathrm{mg} \mathrm{C}$ between 5 and $10 \mathrm{~cm}$ ). Exclusion of the few extremely large individuals produced a pattern with increasing biomass values up to Stn $B$ and a strong decrease below this depth (Fig. 5c, d). Relatively low biomass was found at the shallowest station, Stn 12 $\left(\sim 239 \mathrm{mg} \mathrm{C} \mathrm{m}^{-2}\right)$, and at Stn II ( $147 \mathrm{mg} \mathrm{C}$ $\left.\mathrm{m}^{-2}\right)$; at these stations only small animals were found (Fig. 6a). Omitting the few very large individuals from the mean individual weight produced a pattern with high individual weights at depths around 1000 to $1100 \mathrm{~m}$, with a second peak at a depth of $-3600 \mathrm{~m}$ (Fig. 6b). This pattern is mainly due to the Polychaeta (Fig. 6f).

The vertical distribution of biomass (excluding the few extremely large individuals) in the sediment was not identical to the density pattern either (Fig. 5e), but, as for density, with ANOVA significant interaction between station and layer was found (Table 2). Most remarkable were the relatively low biomass values in the upper $1 \mathrm{~cm}$ at most of the stations (all except Stn B), contrary to the density pattern which had the highest values in the upper $1 \mathrm{~cm}$. Relatively high biomass values were found in the deepest sediment layer $(10$ to $15 \mathrm{~cm})$ at shallow Stn $\mathrm{A}$, whereas at the deeper stations the biomass in this deep sediment layer was relatively low. This is reflected in the vertical distribution pattern of the mean individual weights (Fig. 7a). Mean individual weight with exclusion of the extremely large animals showed significant differences (Table 2). Thus, very few but large animals live in the deeper sediment layers at the shallow stations and high num-

Fig. 5. Macrofauna biomass (mg org. $\mathrm{C} \mathrm{m}^{-2}$ ) (a) along the OMEX transec and (b) along the total depth range sampled. Biomass with exclusion of a few extremely large animals (c) along the OMEX transect and (d) along the total depth range sampled. Relative $(\%)$ importance in biomass (without large individuals) of the different sediment layers (e) along the OMEX transect and (f) along the total depth range

show the same exponential decrease with increasing water depth as density, but instead showed a maximum at Stn B $\left(-2000 \mathrm{mg} \mathrm{C} \mathrm{m}^{-2}\right)$. This relatively high biomass was mainly due to a few large animals [1 Pennatulacea (156 $\mathrm{mg} \mathrm{C}$ ) in the upper sediment layer and 1 Sipuncula ( $291 \mathrm{mg} \mathrm{C}$ ) in the 5 to $10 \mathrm{~cm}$ layer) but also to high mean individual weights of the Crustacea and Polychaeta (Fig. 6d, f). The relatively high biomass at

bers of small animals in the upper $1 \mathrm{~cm}$, especially at Stn I. At the deeper stations the individuals in the upper sediment layers became relatively larger. From among the extra stations, the relatively low density of very small individuals in the upper $1 \mathrm{~cm}$ at $\operatorname{Stn} 8$ is especially remarkable (Figs. 5f, \& 7a). Apart from some extremes, the overall trend of a decrease in relative biomass values in the upper $1 \mathrm{~cm}$ of the sediment with 
increasing water depth is still valid, as is the high value in the upper $1 \mathrm{~cm}$ at $\operatorname{Stn} B$.

The vertical distribution of the mean individual weight of the Polychaeta (Fig. 7b) showed that at all stations small individuals were found in the upper $1 \mathrm{~cm}$ and large individuals in the deeper sediment layers. Comparison with their feeding types showed that it was mainly filterfeeders and surface deposit-feeders that could be found in the upper $1 \mathrm{~cm}$, whereas it was mainly subsurface deposit-feeders in the deeper layers.

\section{Abiotic factors}

Grain size

Median grain size along the OMEX transect decreased with increasing water depth from $-90 \mu \mathrm{m}$ at $\mathrm{Stn} A$ to $\sim 8 \mu \mathrm{m}$ at Stn F, after which it was constant (Fig. 8). The percentage of $\mathrm{CaCO}_{3}$ increased with increasing water depth from $-20 \%$ at Stn A to $-70 \%$ at the deepest stations (Fig. 8). The \% $\mathrm{CaCO}_{3}$ at the extra stations was comparable to those along the OMEX transect as were the median grain sizes at Stns 8,9 and 10. The median grain size at Stn 11 was extremely high; however, it was comparable when $\mathrm{CaCO}_{3}$ was omitted (Fig. 8). This was due to the presence of well sorted foraminiferal sands at this station, probably caused by current focusing at the head of King Arthur canyon (van Weering \& de Stigter 1995). At most of the stations the median grain size was not different with or without $\mathrm{CaCO}_{3}$, except as already mentioned at Stns 11 and I.

The vertical distribution of median grain size and $\% \mathrm{CaCO}_{3}$ showed a very homogeneous sediment to a depth of $15 \mathrm{~cm}$ at all OMEX stations. Only Stn I showed fluctuations in sediment composition with a layer of relatively larger median grain size at $8 \mathrm{~cm}$ and a relatively smaller median grain size between 10 and $15 \mathrm{~cm}$ depth.

\section{C:N ratio}

The organic $\mathrm{C}$ and $\mathrm{N}$ contents of different sediment layers as a function of water depth are shown in Fig. 9. In general organic $C$ increases with depth, but this trend is interrupted by a peak at Stn B $(\sim 1000 \mathrm{~m})$ and values are somewhat lower at the deepest station (Stn E). The picture is more complex for total N, where b

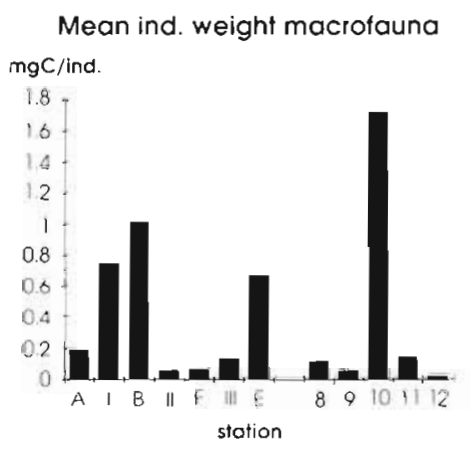

Mean ind. weight macrofauna

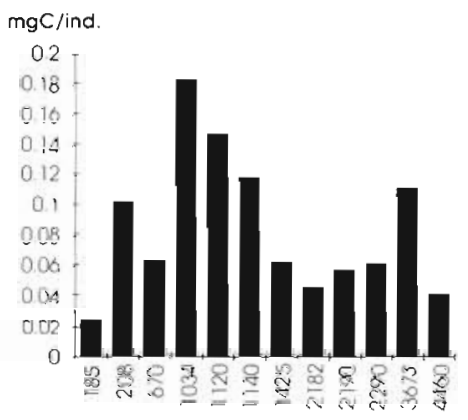

Mean ind. weight Echinodermata
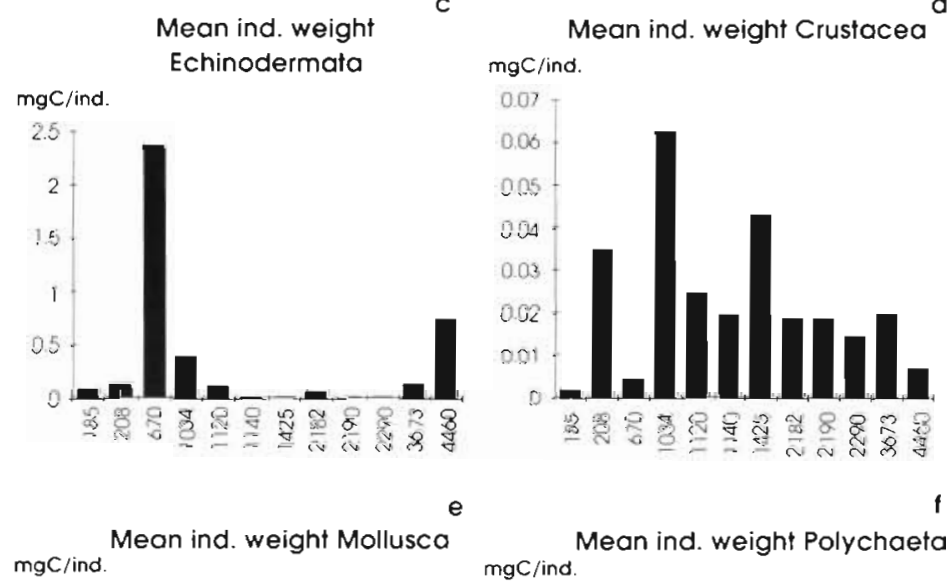

e $\mathrm{mgC} /$ ind

Mean ind. weight Polychaeta
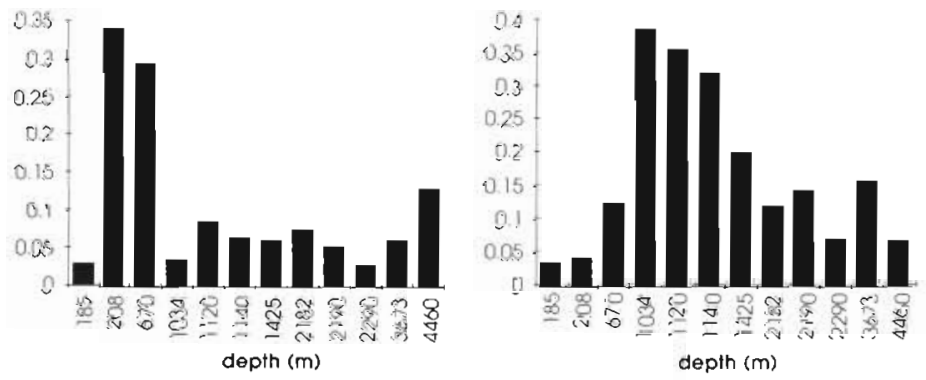

Fig. 6. Mean individual weight (mg org. C) of (a) total macrofauna at the OMEX (A to $\mathrm{E}$ ) and the extra $(8$ to 12$)$ stations. Mean individual weight (mg org. C) omitting a few extremely large individuals of (b) total macrofauna and of (c to t) the 4 major taxa separately along the total depth range sampled

the highest values in all sediment layers are found at the mid-slope Stns B and II and lower values occur both in shallower and deeper water, except for the top sediment layer, which has higher values at greater water depths. In contrast to $\mathrm{C}$, the total $\mathrm{N}$ slightly increases at the deepest station.

The C: $N$ ratio (molar) in the upper $1 \mathrm{~cm}$ of the sediment is around 8 to 9 at the shallow stations, decreases to a minimum at mid-slope Stn II and continues to be low at the deeper stations, slightly increasing to a value of $\sim 10$ at the abyssal station ( $S t n E$ ). The C: $N$ ratio in the 
(a)

\section{Macrofauna without large individuals}
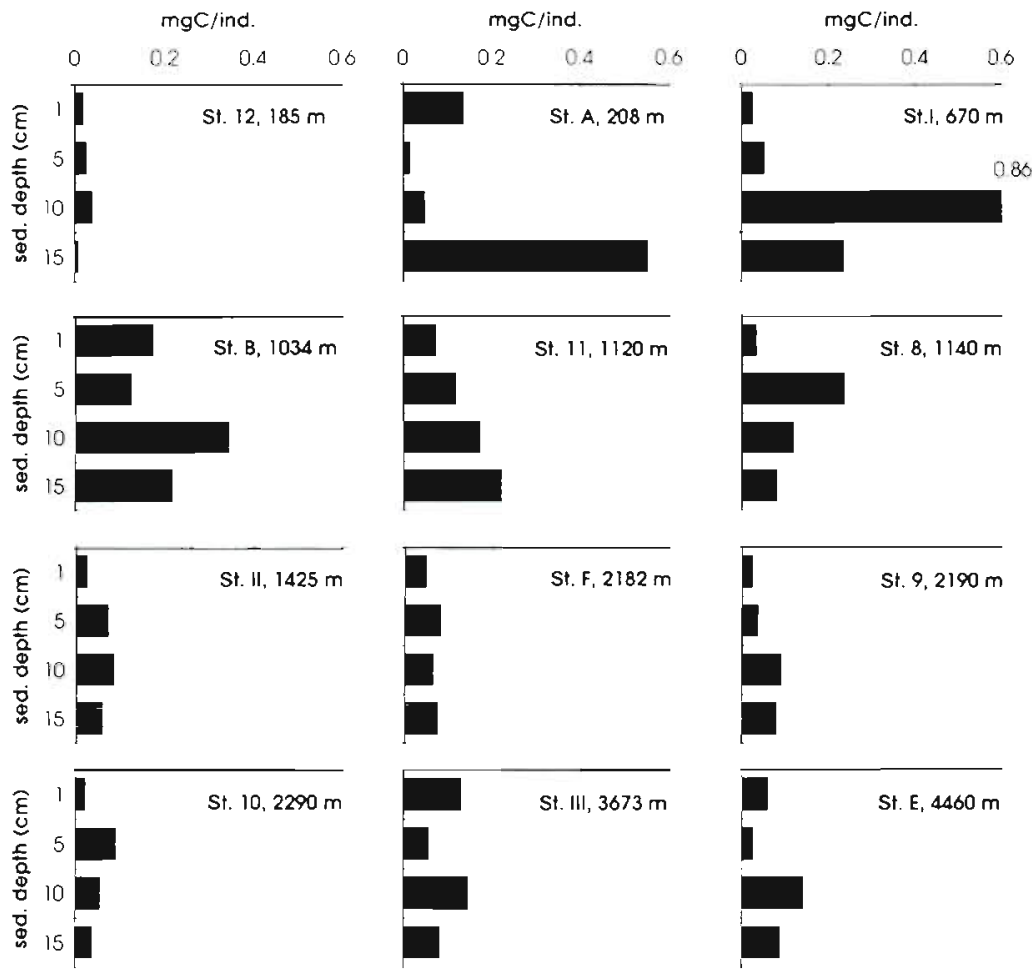

(b)

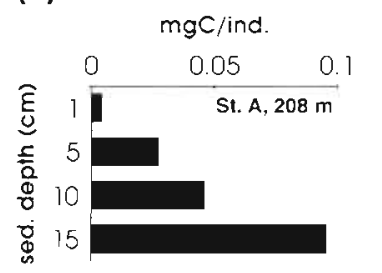

\section{Polychaeta}
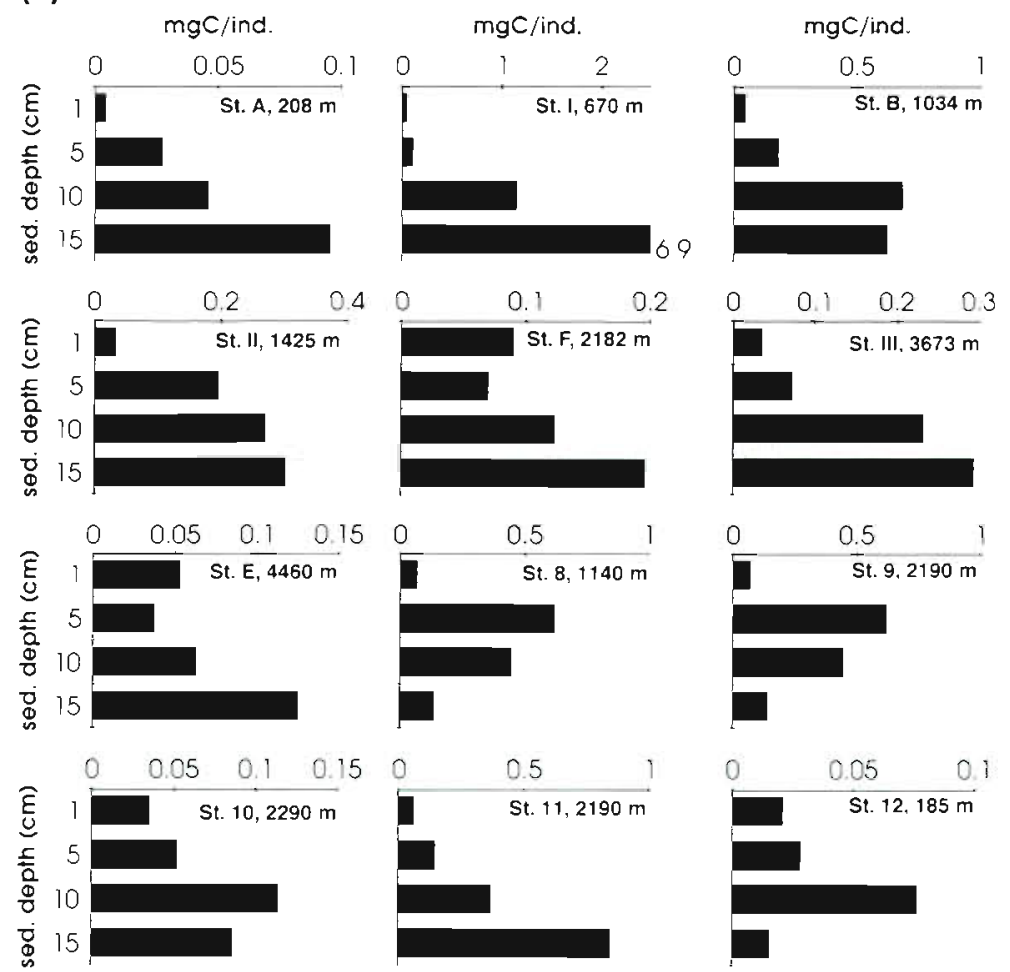

Fig. 7 Vertical distribution of mean individual weight (mg org. C) of (a) total macrofauna (without large individuals) and of (b) the Polychaeta at all stations separately deeper sediment layers decreases from around 10 to 12 at the shallowest stations to between 6 and 7.5 at mid-slope Stn II and then increases again to values of around 12 to 15 at the deeper stations. At the abyssal station the values decrease again. At mid-slope Stns B and II the $C: N$ ratio is approximately constant to a depth of $15 \mathrm{~cm}$ (Fig. 9).

\section{DISCUSSION}

The macrofauna densities along the OMEX transect follow the usual trend of exponential decrease with increasing water depth. The 5 extra stations fit well within the trend of the transect, indicating that the OMEX transect is representative of the Goban Spur area. The observed trend also fits well with the known values from the literature, although comparison is often difficult because of methodological problems, mainly differences in mesh size of the sieve used (Rowe 1983). Most of our stations fit well on the line for the northwest Atlantic (Fig. 10a) given by Jumars \& Gallagher (1982, Fig. 10-3), except the 2 deepest stations (3673 and $4460 \mathrm{~m}$ ), which are closer to the line for the Bay of Biscay. This resulted in a less steep decline along the OMEX transect compared to the line given for the northwest Atlantic. For the data points of the OMEX transect and the 5 extra stations the equation $y=3.83544-0.00028 \times(y=$ $\log _{10}$ no. of ind $\mathrm{m}^{-2}$ and $x=$ depth in $\mathrm{m}$, $\mathrm{R}=-0.94, \mathrm{p}<0.001, \mathrm{n}=28$ ) was fitted (Fig. 10a). Fig. 10a also shows the small differences in numbers between the boxcores per station. Gage (1979) also found low variance between replicate box cores taken at one $2875 \mathrm{~m}$ deep spot in the Rockall Trough and concluded that single core samples could therefore be regarded as representative of their respective areas. The only station that did not fit this equation well was Stn $8(1140 \mathrm{~m})$, which was situated on the OMEX transect, but which had relatively low densities. These low values were mainly due to relatively low numbers in the upper $1 \mathrm{~cm}$ of the sediment (Fig. 2b, d). 

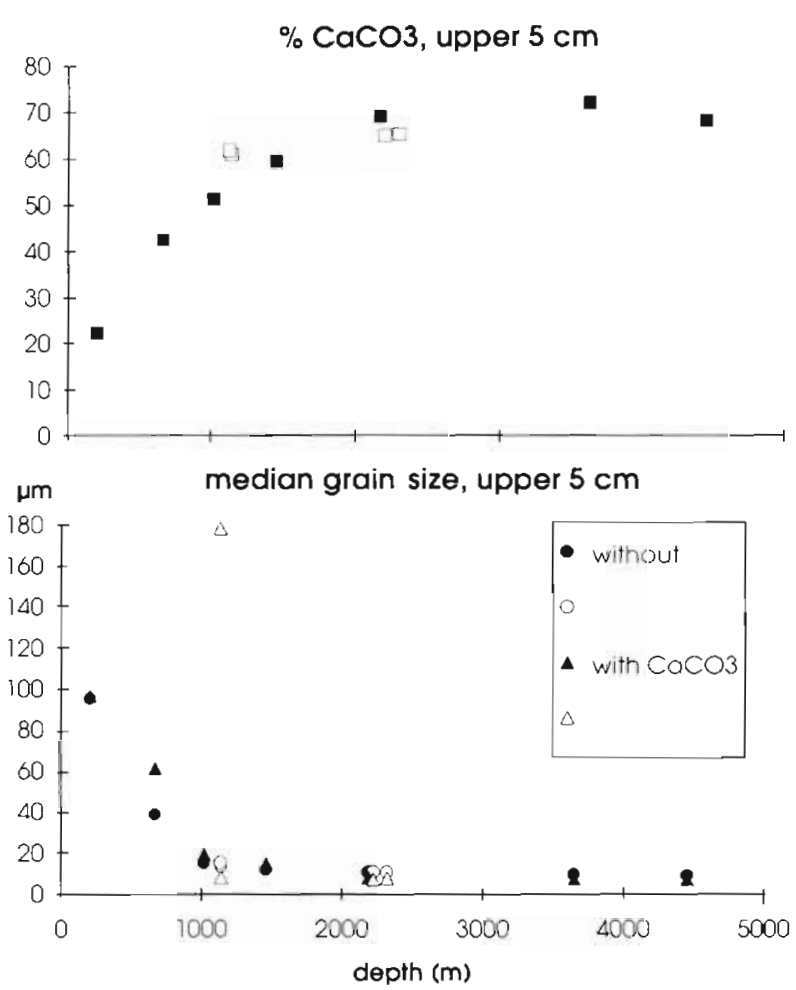

Fig. 8. Percentage $\mathrm{CaCO}_{3}$ and the median grain size $(\mu \mathrm{m})$ with and without $\mathrm{CaCO}_{3}$ in the upper $5 \mathrm{~cm}$ of the sediment along the total depth range. Closed symbols are the OMEX stations and open symbols are the extra stations

The importance of the upper sediment layer for the macrofauna is stressed in all literature dealing with vertical distribution. The trend found along the OMEX transect with an increase in importance of the upper $1 \mathrm{~cm}$ from $\sim 200 \mathrm{~m}$ to $\sim 1000 \mathrm{~m}$ water depth was also found by Josefson (1989) from $100 \mathrm{~m}$ to $620 \mathrm{~m}$, whereas Shirayama \& Horikoshi (1982) found the opposite trend along their transect from $115 \mathrm{~m}$ to $472 \mathrm{~m}$ water depth. Grehan et al. (1994) found an increase of importance of the upper $3 \mathrm{~cm}$ from $240 \mathrm{~m}$ to $325 \mathrm{~m}$ and a decrease at deeper stations with a relatively more even distribution at their deepest station $(815 \mathrm{~m})$. This shows that, although trends in vertical distribution along depth gradients have been found at most places, no general depth-related pattern could be observed, and other factors besides depth must be responsible for the vertical distribution patterns. This is illustrated in Schaff \& Levin (1994), who, for 2 stations at $850 \mathrm{~m}$ water depth situated $\sim 130 \mathrm{~km}$ apart, found 2 different vertical distribution patterns.

The decrease of relative densities in the upper $1 \mathrm{~cm}$ with water depth from $1034 \mathrm{~m}$ to $4460 \mathrm{~m}$ as found along the OMEX transect has not been reported before. The vertical distribution observed by Blake (1994) along the continental slope of Cape Lookout (NC, USA) was based on pooled samples over a depth
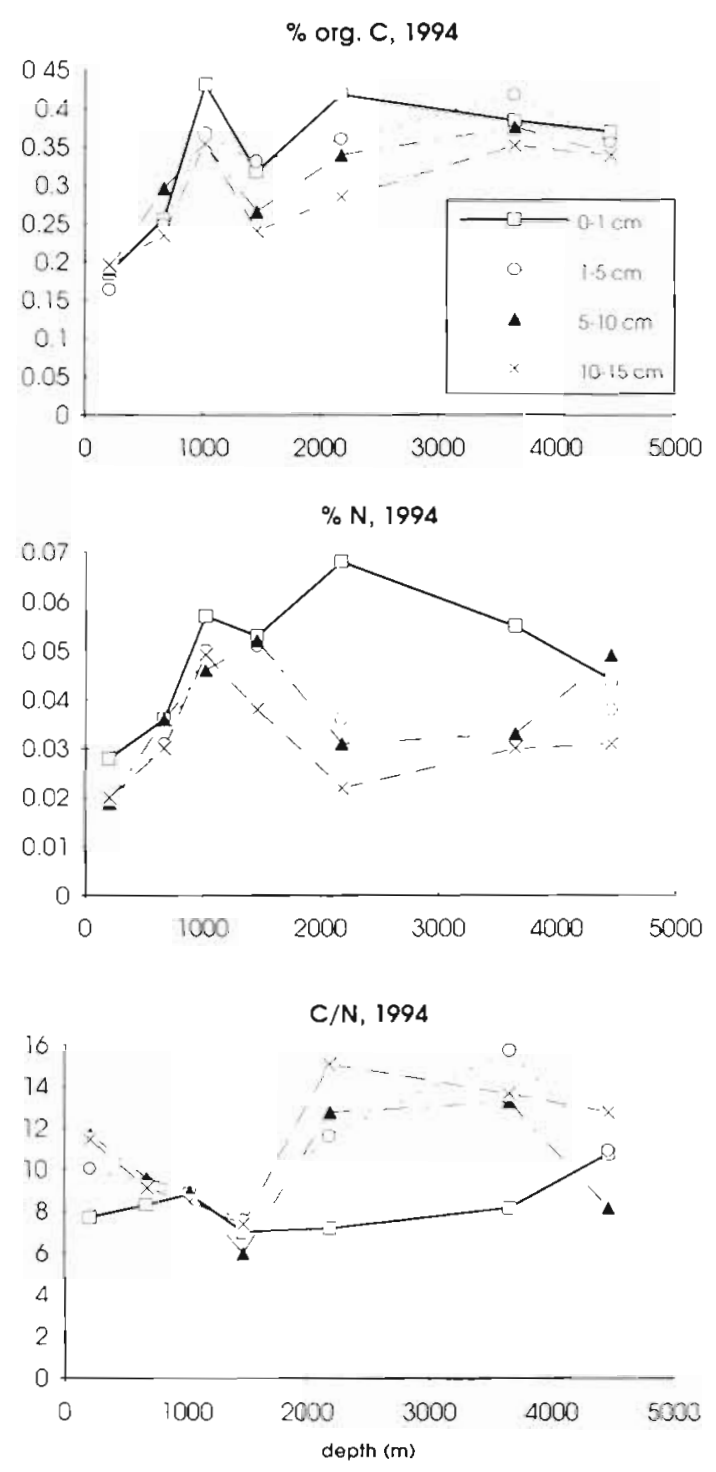

Fig. 9. Percentage in the sediment of total nitrogen ( $N$ ) and organic carbon (org. C) and the C:N ratio (molar) in the different layers of the sediment $(0-1,1-5,5-10,10-15 \mathrm{~cm})$ along the OMEX treatment

range of 583 to $3000 \mathrm{~m}$. He found for most taxa that more than $50 \%$ of the individuals were concentrated in the upper $2 \mathrm{~cm}$ of the sediment, e.g Polychaeta $55.5 \%$, Mollusca $70.1 \%$, Echinodermata $69.6 \%$ and Crustacea (Amphipoda + Isopoda + Tanaidacea) $64.7 \%$. The OMEX data pooled over a comparable depth range $(670$ to $2182 \mathrm{~m}, 4$ stations) gave Echinodermata $82.7 \%$, Crustacea $72.9 \%$, Mollusca $77.2 \%$ and Polychaeta $68.9 \%$ in the upper $1 \mathrm{~cm}$ of the sediment. Thus, a higher proportion of the 4 major taxa was found in the upper $1 \mathrm{~cm}$ of the sediment along the continental slope of the Goban Spur area than in the upper $2 \mathrm{~cm}$ along the continental slope of Cape Lookout. 

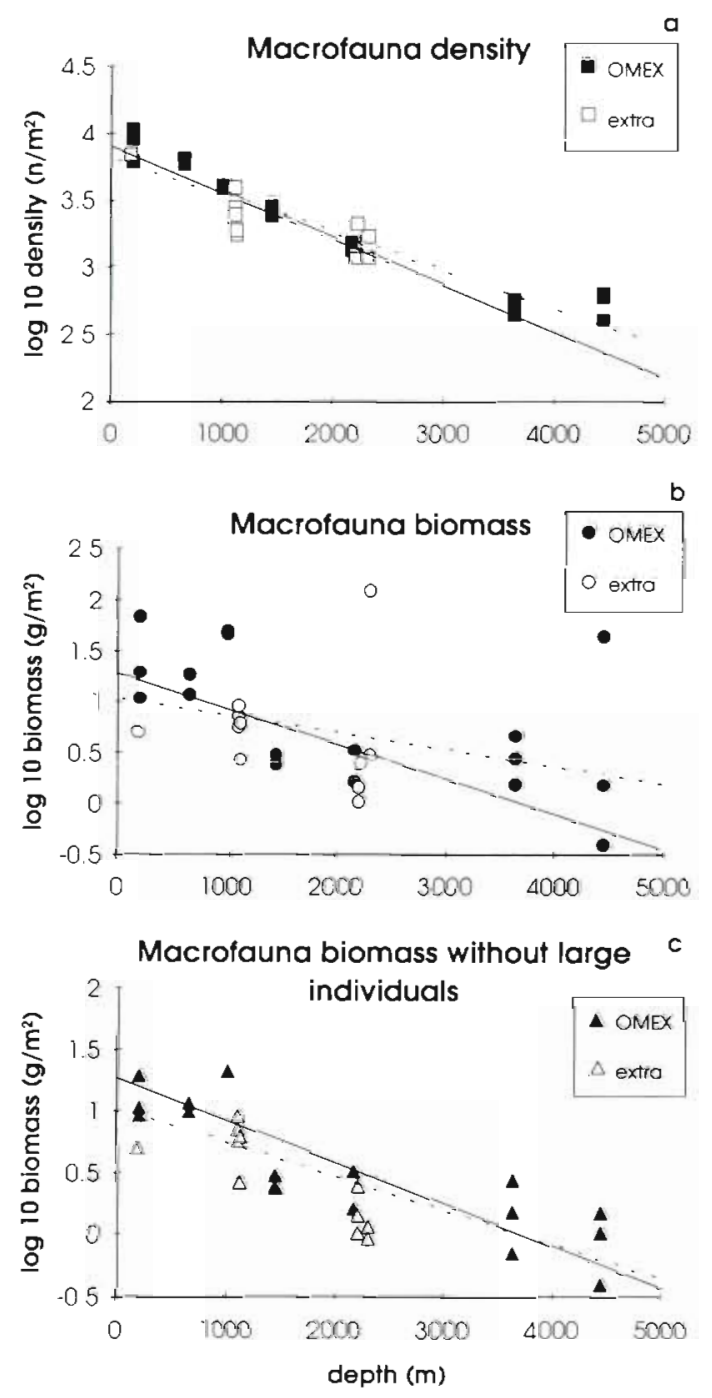

Fig. 10. (a) Macrofauna densities $\left(\log _{10} \mathrm{n} \mathrm{m}^{-2}\right)$ per boxcore along the depth gradient in the Goban Spur area [regression line $(---), y=3.83544-0.00028 x, R=-0.94, S D=0.14286$, $\mathrm{p}<0.001, \mathrm{n}=28$ ] compared to the solid line given for the northwest Atlantic by Jumars \& Gallagher (1982). (b and c) Macrofauna biomass along the depth gradient in the Goban Spur area, compared to published values (—), $y=1.25$ $0.00039 \times$ given by Rowe (1983). (b) Total biomass, regression line (- - -), $y=1.07073-0.00018 x, \mathrm{R}=-0.41, \mathrm{SD}=0.54662$, $p=0.03, n=28$. (c) Blomass with some extremely large ind $1-$ viduals excluded (mentioned in text), regression line (- - - ) $y=1.01841-0.00027 x, R=-0.81, S D=0.2702, p<0.001, n=28$

Jumars (1978) found $58.2 \%$ of the macrofauna and $56.2 \%$ of the Polychaeta in the upper $1 \mathrm{~cm}$ of the sediment at a station at $1220 \mathrm{~m}$ water depth in the San Diego Trough. However, assuming that all filter-feeders and surface deposit-feeders live in the upper $1 \mathrm{~cm}$ of the sediment, this value should be much higher $(81.6 \%)$. The lower value found was attributed to withdrawal of the animals into tubes and burrows, caused by disturbance during coring. Our values are much higher, $75 \%$ of the Polychaeta were found in the upper $1 \mathrm{~cm}$ of the sediment at the stations at 1034 and 1425 $m$, including all filter-feeders and $-95 \%$ of the surface deposit-feeders. Therefore we feel that our vertical distribution pattern is representative of the field situation.

Macrofaunal biomass along the Goban Spur transect does not follow the classical pattern of a monotonous decrease with depth. A regression line of $y=1.07073-$ $0.00018 x\left(y=\log _{10}\right.$ biomass in $g$ wet wt $\mathrm{m}^{-2}, x=$ depth in $m, R=-0.41, p=0.03, n=28$ ) was found (Fig. 10b), which was not comparable to the line given by Rowe (1983), $y=1.25-0.00039 x$. The difference is caused by a few stations with relatively high biomass values. At these stations 1 or 2 extremely large individuals were found. Exclusion of these large individuals (i.e. 1 Echinoidea at Stn A, 1 Polychaeta at Stn I, 1 Pennatulacea + 1 Sipuncula at Stn B, 1 Ophiuroidea at Stn III, 1 Holothuroidea at Stn E and 2 Sipuncula at Stn 10) resulted in a regression line (Fig. 10 C: $y=1.01841$ $0.00027 x, \mathrm{R}=-0.81, \mathrm{p}<0.001, \mathrm{n}=28$ ) which is closer to, but still less steep than, the line found by Rowe (1983). Thus, both in density and in biomass the deepest OMEX stations have relatively high values. Fig 10 also shows that biomass values were also more variable between the samples at any one station than were the density values, even when large individuals were excluded.

Stn $B$ at $1034 \mathrm{~m}$ had by far the highest biomass value even with exclusion of the 2 extremely large individuals $\left(\sim 858 \mathrm{mg} \mathrm{C} \mathrm{m}{ }^{-2}\right)$. Biomass was mainly $(\sim 80 \%)$ concentrated in the upper $1 \mathrm{~cm}$ at this station. At Stn III $(3673 \mathrm{~m})$ also, most of the biomass $(\sim 60 \%)$ was concentrated in the upper $1 \mathrm{~cm}$ of the sediment, and this station also had a relatively high biomass value. These high biomass values were mainly due to high mean individual weights (without large individuals), which showed a clear maximum at $1034 \mathrm{~m}$ and a second peak at $3673 \mathrm{~m}$ (Fig. 6b). High biomass values and high mean individual weights imply good feeding conditions. However, no direct correlation with either \% POC nor \% $N$ nor with $C: N$ ratio could be found. Sibuet et al. (1989) conclude that, because about $~ 85 \%$ of the sedimenting organic $C$ is utilized before burial, the organic carbon within the surface sediments mainly represents what the biomass did not consume and not what is available for consumption. They also conclude that the flux of organic $\mathrm{C}$ settling at the sediment-water interface controls the biomass distribution in the deep Atlantic Ocean. Biomass values can therefore give an indication of the $\mathrm{C}$ flux. However, not only the quantity but also the quality and the pattern of food input are important for the fauna (Rex 1983).

The relationship between organic food supply and expected vertical distribution has been discussed by 
Jumars et al. (1990). Along the OMEX transect we have 2 extremes, $\operatorname{Stn} B$ where most of the macrofauna $(-80 \%)$ is concentrated in the upper $1 \mathrm{~cm}$ and Stn E where most of the macrofauna $(\sim 60 \%)$ is found below the surficial sediment layer At Stn B relatively high numbers of filter- and surface deposit-feeding Polychaeta were found together with some large Pennatulacea and Sipuncula. To support this community, a high flow velocity with a relatively high suspended load (horizontal transport) is needed for the filter-feeders and surface deposit-feeders. Current velocities along the OMEX transect have been measured by Graf \& Thomsen (1995), who found high average velocities of $30 \mathrm{~cm}^{-1}$ at Stn B in October 1993. Pulses of labile matter (vertical transport) are needed to support the high densities of small animals (e.g. a high number of juvenile Ophiuroidea in May and June) in the surface layer (Jumars \& Gallagher 1982, Jumars et al. 1990). Soetaert et al. (1995) calculated from their diagenetic model that the $\mathrm{C}$ arriving at this station must be very reactive, with a mean degradability of $0.037 \mathrm{~d}^{-1}$, therefore consisting mainly of fresh material. High current velocities transporting reactive material explain the high biomass value found at this station. At Stn $E_{\text {, on }}$ the other hand, mainly deep-living subsurface depositfeeders were found, which are favoured by a steady, slow sedimentation of refractory organic material (Rice \& Rhoads 1989).

The amounts of organic $C$ and total $N(\sim 2$ to $5 \mathrm{mg}$ org. $\mathrm{C} \mathrm{g} \mathrm{g}^{-1}$, and $\sim 0.3$ to $0.7 \mathrm{mg} \mathrm{N} \mathrm{g}^{-1}$, respectively) found in the sediments are comparable to most published data for the Atlantic (Thistle et al. 1985, Sibuet et al. 1989, Santos et al. 1994), although the organic C values found along the SEEP-II transects (Anderson et al. 1994) were somewhat higher. The decrease within the sediment that is often found (Thistle et al. 1985 , Santos et al. 1994) was also found in our study. A decrease with depth was not found in the profiles of the SEEP-II study (Anderson et al. 1994). The midslope depocenter at $\sim 1000 \mathrm{~m}$ water depth, found on the SEEP-II transect, was mirrored in the peaks of both C and $N$ present at mid-slope depths of the OMEX transect, and also the highest biomass value found at Stn B at $1034 \mathrm{~m}$. The increase in $\% \mathrm{~N}$ with increasing water depth could suggest less food limitation (as $\mathrm{N}$ is often the limiting factor, Jumars et al. 1990) for the infauna, although it could also just mean that a smaller amount of the arriving $N$ is used by the fauna (as the percentage of the organic matter used by the fauna decreases with increasing depth, Smith \& Hinga 1983).

Values of the C:N ratio for oceanic conditions have been summarized by Martin \& Sayles (1994), who report a range of a factor of $\sim 2$, from 5.4 to 12 . At the Hatteras continental rise the ratio was 8.6 and 8.4 , higher than in the Hatteras abyssal plain (5.4 to 7.0).
Sediment trap measurements show that the $\mathrm{C}: \mathrm{N}$ ratio at a site increases with depth and sediments have $\mathrm{C}: \mathrm{N}$ ratios that are systematically higher than that in deeper sediment traps at the same location. This indicates that $\mathrm{N}$ is recycled more rapidly than $\mathrm{C}$ (Suess \& Müller 1980). These values are similar to the ones found by us in the upper $1 \mathrm{~cm}$, but very different from the deeper sediment layers, a pattern that suggests that at the deeper slope stations fresh material had been recently deposited. The $\mathrm{C}: \mathrm{N}$ ratio at the midslope Stns B and II were more or less similar throughout the whole sediment column to a depth of $15 \mathrm{~cm}$, suggesting a rapid burying of organic matter to deeper sediment layers by surface deposit-feeders. Indeed, high proportions of surface deposit-feeding Polychaeta (and at Stn B also some large Sipuncula) were found at these stations.

The homogeneous vertical distribution pattern in grain size within the sediment suggests either a very constant accumulation or a continuous mixing by bioturbation. Food and food intake are the main factors which relate benthic biology to sedimentation and features of the benthic boundary layer The bulk ingestion and subsequent egestion of particles, typically containing less than $5 \%$ of metabolizable matter, by deposit feeders is the dominant particle-mixing activity in nearly all sediments (Aller 1982). Along the OMEX transect a high amount of deposit-feeders ( 55 to $85 \%$ ) were found to a depth of at least $15 \mathrm{~cm}$ in the sediment and larger animals occurred in these deeper layers (Fig. $7 \mathrm{~b})$. Because the bioturbation coefficient $D_{\mathrm{b}}$ is related to body length $L$ as $D_{\mathrm{b}} \approx L^{4.25}$ (Wheatcroft et al. 1990) and deposit feeders process several times their own body weight in sediment each day (Lopez \& Levinton 1987). bioturbation by these large deposit feeders is probably the cause of the homogeneous grain size distribution found to a depth of $15 \mathrm{~cm}$ along the OMEX transect.

Acknowledgements. The authors are very grateful to Adri Sandee for taking the samples during the cruise. We thank Mark Lavaleye (NIOZ, Texel) for determination of the Polychaeta, Joop Nieuwenhuize for analysing the sediment composition in co-operation with Adri Sandice and Peter Herman for stimulating discussions. We also thank the crew of the RV 'Charles Darwin' and the colleagues of NIOZ, Texel for the support received during the cruise. This study was financially supported through the OMEX programme [MAST II, Ass. contract no. 20 (Mas2-CT93-0069)] and ship-time on the RV 'Charles Darwin' was funded by the Netherlands Marne Research Foundation SOZ (now Netherlands Geosciences Foundation GOA). NIOO publication no. 2149.

\section{LITERATURE CITED}

Aller RC (1982) The effects of macrobenthos on chemical properties of marine sediment and overlying water. In: McCall PL, Tevesz MJ (eds) Animal-sediment relations: the biogenic alteration of sediments. Plenum Press. New York, p 53-102 
Anderson RF, Rowe GT, Kemp PF, Trumbore $\mathrm{S}$, Biscaye PE (1994) Carbon budget for the mid-slope depocenter of the Middle Atlantic Bight. Deep Sea Res II 41 (2/3):669-703

Blake JA (1994) Vertical distribution of benthic infauna in continental slope sediments of Cape Lookout, North Carolina. Deep Sea Res II 41 (4-6):919-927

Boudreau BP (1994) Is burial velocity a master parameter for bioturbation? Geochum Cosmochim Acta 58 (4):1243-1249

Fauchald K, Jumars PA (1979) The diet of worms: a study of polychaete feeding guilds. Oceanogr Mar Biol Ann Rev $17: 193-284$

Gage JD (1979) Macrobenthic community structure in the Rockall Trough. Ambio Spec Rep No 6:43-46

Gage JD, Tyler PA (1991) Deep-sea biology: a natural history of organisms at the deep-sea floor. Cambridge University Press, Cambridge

Grat G. Thomsen L (1995) The benthic resuspension loop at the shelf break and on the continental slope. OMEX 2nd Ann Rep Part E:29-35

Grehan AJ, Scaps P, Desrosiers G, Juniper K, Stora G (1994) Vertical macrofaunal distribution in the soft sediments of the Gulf of St. Lawrence and the Scotian Continental Margin: a preliminary assessment of inlersite differences in bioturbation potential. Vie Milieu 44 (2):101-107

Josefson AB (1989) Do subsurface deposit-feeders partition resources by vertical stratification in the sediment? In: Ros JD (ed) Marine biology. Sci Mar 53 (2-3):307-313

Jumars PA (1978) Spatial autocorrelation with RUM (Remote Underwater Manipulator): vertical and horizontal structure of a bathyal benthic community. Deep Sea Res 25: $589-604$

Jumars PA, Gallagher ED (1982) Deep sea community structure: three plays on the benthic proscenium. In: Ernst WG, Morin JG (eds) The environment of the deep sea. Prentice Hall, Inc, Englewood Cliffs, NJ, p 217-255

Jumars PA, Mayer LM, Deming JW, Baross JA, Wheatcroft RA (1990) Deep-sea deposit-feeding strategies suggested by environmental and feeding constraints. Phil Trans $R$ Soc Lond A Math Phys Sci 331:85-101

Lopez GR, Levinton JS (1987) Ecology of deposit-feeding animals in marine sediments. Q Rev Biol 62:235-260

Martin WR, Sayles FL (1994) Seafloor diagenetic fluxes. In: Material fluxes in the surface of the earth. National Academy Press, Washington, DC, p 143-163

Nieuwenhuize J, Maas YEM, Middelburg JJ (1994) Rapid analysis of organic carbon and nitrogen in particulate materials. Mar Chem 45:217-224

Rex MA (1983) Geographic patterns of species diversity in deep-sea benthos. In: Rowe GT (ed) Deep-sea biology

This article was submitted to the editor
The sea, Vol 8. John Wiley \& Sons, New York, p 453-471

Rice DL, Rhoads DC (1989) Early diagenesis of organic matter and the nutritional value of sediment. In: Lopez GR, Taghon GL, Levinton JS (eds) Ecology of marme deposit feeding. Springer-Verlag, New York, p 59-79

Rowe GT (1983) Biomass and production of deep-sea macrobenthos. In: Rowe GT (ed) Deep-sea biology. The sea, Vol 8. John Wiley \& Sons, New York, p 97-121

Santos V, Billet DSM, Rice AL, Wolff GA (1994) Organic matter in deep-sea sediments from the Porcupine Abyssal Plain in the north-east Atlantic Ocean. I - Lipids. Deep Sea Res I 41(5/6):787-819

Schaff TR, Levin LA (1994) Spatial heterogeneity of benthos associated with biogenic structures on the North Carolina continental slope. Deep Sea Res II 41(4-6):901-918

Shirayama Y, Horikoshi M (1982) Vertical distribution of smaller macrobenthos and larger meiobenthos in the sediment profile in the deep-sea system of Suruga Bay (Central Japan). J Oceanogr Soc Jpn 38:273-280

Sibuet M, Lambert CE, Chesselet $R$, Laubier L (1989) Density of the major size groups of benthic fauna and trophic input in deep basins of the Atlantic Ocean. J Mar Res 47 $8.51-867$

Smith KL, Hinga KR (1983) Sediment community respiration in the deep sea. In: Rowe GT (ed) Deep-sea biology. The sea, Vol 8. John Wiley \& Sons, New York, p 331-370

Soetaert K, Herman PMJ, Middelburg JJ, Epping E, Helder W (1995) Applying the coupled diagenetic model to OMEX sediments - preliminary results. OMEX 2nd Ann Rep Part C:63-64

Soetaert K, Herman PMJ, Middelburg JJ (1996) A model of early diagenetic processes from the shelf to abyssa! depths. Geochim Cosmochim Acta 60 (6):1019-1040

Suess E, Müller PJ (1980) Productivity, sedimentaion rate and sedimentary organic matter in the oceans II. Elemental fractionation. Colloq Int Cent Natl Rech Sci, No 293:17-26

Thistle D, Yingst JY, Fauchald K (1985) A deep-sea benthic community exposed to strong near bottom currents on the Scotian Rise (Western Atlantic). Mar Geol 66:91-112

van Weering TjCE (1994) Cruise report OMEX, 18/5-13/6 1994, with R.R.S. Charles Darwin. NIOZ, Texel, The Netherlands

van Weering TjCE, de Stigter $H$ (1995) Recent sediments, boundary layer dynamics and sediment accumulation at the Goban Spur margin. OMEX 2nd Ann Rep Part E:15-28

Wheatcroft RA, Jumars PA, Smith CR, Nowell ARM (1990) A mechanistic view of particulate biodiffusion coefficients: step lengths, rest periods and transport directions. J Mar Res 48:177-207

Manuscript first received: December 27, 1995

Revised version accepted: June 25, 1996 